\title{
Influence of Heavy Metals on the Environment and Methods of Soil Bioremediation Control
}

\author{
Baibotayeva A.Dikhanbaevna $^{1 *}$, Zhantasov K.Tazhmahanbetovich ${ }^{1}$, Kenzhaliyeva G. Duysenbaevna ${ }^{1}$, \\ Bosak V. Nikolaevich ${ }^{2}$, Mamitova A.Dzhanabaevna ${ }^{1}$
}

${ }^{1}$ M. Auezov South Kazakhstan state University, 160000, Tauke khan av 5, Shymkent, Kazakhstan.

${ }^{2}$ EI "Belarusian State Agricultural Academy", Gorky, Mogilev region, Republic of Belarus.

ORCID: 0000-0001-8560-9218 (Baiboteyeva)

\begin{abstract}
The article presents data from literature and patent information on the analysis of heavy metals formed during the extraction and processing of various types of raw materials for the production of non-ferrous metals and chemical products. The effects of heavy metals on the environment and living organisms, fauna and flora, as well as people living in different industrial regions of Kazakhstan are shown.The migration of heavy metals in the soil cover of the lithosphere, hydrosphere, and atmosphere of the planet Earth is presented. On the basis of the analytical review, the goals and objectives of the study are set, the chemical composition of raw materials for the main heavy metals formed in solid and dust - like wastes of production, for technological processing in the production of lead and zinc in the East Kazakhstan and South Kazakhstan regions is given. Information is given on soil analysis conducted in the territory of the Turkestan region in nearby mining complexes and enterprises producing lead and zinc and recreation areas. The distribution of heavy metals and the chemical composition of the analyzed samples taken at various points in the Turkestan region and the Shymkent city are shown.
\end{abstract}

Keywords: Control, Cleaning, Dust and gas mixture, Heavy metals, Bioremediation, Soil

\section{INTRODUCTION}

The problem of utilization and improvement of technologies for processing raw materials containing heavy and other metals in the southern regions of the Republic of Kazakhstan, as well as cross-border countries of the world with our state is relevant.

This is due to the fact that industrial enterprises located in our Republic have a close relationship with the processing of raw materials containing heavy metals and having some affinity with them, such as arsenic and phosphorus, whose gaseous compounds are poisonous and harmful substances. For periods of phosphorus and svinopogolove in the post-Soviet era, with ' 60 s to the 90 s of the last century the environment was dumped tens and hundreds of thousands of tons of waste phosphorus and lead industries located within the city of Shymkent.

Soil cover is one of the most important entities whose value for human life and the environment is determined by the fact that it is the main source of food, industrial and agricultural enterprises, etc., not only in Kazakhstan but also in other countries of the globe. In addition, the most important property of the soil is its fertility and providing a crop of high quality and quantity. The natural fertility of the soil cover is regulated by the supply of nutrients, which can be influenced by various factors-impurities and soil pollutants.

Man-made pollution of the environment has a negative impact on the fauna and flora of the globe and threatens humanity on the verge of an environmental disaster. This problem is especially dangerous for irrigated lands, since without preventive measures that allow to completely remove or reduce the content of heavy metals that have a Toxicological effect on living organisms, including humans, soil pollution progresses.

Heavy metals include more than 40 chemical elements, the mass of whose atoms is more than 50 atomic units (a. e. m.). The main metals that pollute the soil are: lead, zinc, cadmium, mercury, copper, manganese, tungsten, tin, cobalt, arsenic, etc.

The authors [1] found that lead pollution occurs mainly as a result of burning gasoline $(60 \%)$, production of non-ferrous metals $(22 \%)$, and production of iron, steel, and ferroalloys $(11 \%)$.

According to the work [2], in some soils there was an increase in chromium by 2 times, led by 1.8 times, copper, vanadium and Nickel by 1.4 and zinc by 1.2 times.

Ongoing work to reduce heavy metals in soils contaminated with petroleum products does not provide clear results in a coordinated reduction of them in the soil cover.

For example, the authors [3] investigated the ecological state and found that the main environmental pollution of the Aktobe region is caused by the technogenic impact of the chrome and boron industries, where the Yuzhno Kempirsayskoye Deposit of chrome ores, large plants of chrome compounds and ferroalloys using boron oxide for the enrichment of chrome ores are located.

Sources of heavy metals entering the soil by their nature are divided into natural and man-made.

Natural sources of heavy metals entering the soil include weathering of rocks and minerals, erosion processes, volcanic eruptions and their activities. 
Technogenic sources of heavy metals include mining and processing of minerals, fuel combustion, the use of motor vehicles and technical means of the agro-industrial complex during agrochemical operations, the spill of petroleum products and oils, during the extraction and processing of raw materials, waste water, as well as non-ferrous metallurgy enterprises [4-16]. Therefore, the role of soil cover on the life and productivity of terrestrial ecological systems is very large. The soil feeds land plants with water and many macro-and micro-fertilizers, which are the most important component of photosynthetic processes in plants, ornamental shrubs and agricultural crops for General use of human life and the surrounding fauna and flora.

Soil contamination heavy metals has two negative characteristics:

- flow from the soil to plants, from plants to the human body and animals, causing serious diseases and reducing vital activity due to Toxicological effects, the quantity and quality of agricultural products;

- accumulating in the soil in large quantities, they change the physical, chemical, biological and other properties of the soil cover.

Decreases in the biological properties of soils lead to a General decrease in the number of microorganisms and a narrowing of their diversity (species composition), changes in the structure of microbiocenoses and microbioecological processes occurring in the soil, as well as a decrease in the activity of soil enzymes, the structure of the humus state and $p H$ of the environment.

These phenomena lead to a partial or total loss of soil cover fertility, an increase in the process of dust formation and its removal by winds, as well as atmospheric precipitation, leading to natural geochemical anomalies, such as soil formation, which controls the transfer of chemical elements to the atmosphere, hydrosphere, lithosphere and biosphere, i.e. living organisms. All this also affects the transfer and deviation of the norm of the mineral composition of the soil along the above chain-from the plant organism to the organism of living beings, reducing their vitality. In addition, soil, river and waste water from industrial sources differ significantly in their chemical composition from natural resources, since the chemical, metallurgical, petrochemical industries, energy and other industries are sources of emissions into the atmosphere and hydrosphere of various pollutants, including heavy metals.

\section{MATERIALS AND METHODS}

The object of the study is the environmental safety of the territories of industrial regions, in order to ensure the safety of the population, fauna and flora.

The subject of the study is soil contamination with lead, arsenic, copper, cadmium and zinc, and the possibility of their biotesting by phytoremediation method.

Heavy metals have a significant impact on the deterioration of the structural and agrochemical properties of the soil. This leads to an increase in spore-bearing fungi, bacteria, and in many cases, to the death of plants. Once in the water, they cause irreparable damage to the ecological system, participating in redox processes, due to variable valence, changing complexing properties.

The danger of the influence of heavy metals on humans and animals is manifested not only in the direct impact of high concentrations and accumulations in the body, but also in the fact that they are difficult to remove and have a Toxicological effect with the possibility of abnormal diseases and poisoning.

An example of this can be the research of a number of authors of scientific papers [5-7, 14-16] on the identification and impact on the environment of $\mathrm{Pb}, \mathrm{Zn}, \mathrm{Wi}, \mathrm{Cu}, \mathrm{W}, \mathrm{Co}$, etc. This is due to the migration of heavy metals along with dust and gases emitted and carried away from sources of formation of heavy metals.

For example, the Mangistau region is one of the regions of Kazakhstan with a rather tense radio-ecological situation. This is related to the extraction and processing of radioactive raw materials, using it for energy, industrial, medical and research purposes. Radioecological conditions are determined by the degree of saturation of dangerous objects of natural and manmade origin. Dangerous man-made radioecological objects include sinkholes over the site of underground nuclear explosions Sayotes, the koshkarata tailings storage facility, places where radioactive waste is stored at MAEK industrial sites, uranium quarries and waste from the oil industry.

Analysis of soil data and soil maps of the Mangistau region allowed us to determine the main factors that affect the degree of their environmental disturbance, to identify the prevailing types of soil pollution and salinization. The region's indicators for soil bonitet are very low, which is due to the low content of humus in zonal soils and the presence of negative signs, such as salinity, salinity and gravel. Only in certain areas of the region that are used for irrigated arable land, the bonus score is higher [17].

Identified the entrance of the analysis of literature and patent information indicate that contamination located in the vicinity of industrial enterprises in the mining of non-ferrous metallurgy and, in particular, for recycling of their lead and zinc, the presence of the elemental composition of heavy metals and degree of contamination they have different meanings. This is due, in our opinion, to the direction of the prevailing wind and the presence of the level of MPC of heavy metals above the norms, which is common for industrial regions and in the soils of nearby cities and towns.

Based on these data, the analysis of patent information on methods for determining, disposing of and clearing contaminated soils of heavy metals was carried out [13-20]. In addition, work was established to determine heavy metals in the human body, for example, the enterprises of JSC "Kazzinc (Ust - Kamenogorsk lead-zinc plant) and JSC" UKTMK "(Ust-Kamenogorsk titanium-magnesium plant) spreading within the city of Ust-Kamenogorsk, East Kazakhstan region of the Republic of Kazakhstan [15].

Heavy metals arrive at the soil surface in various forms - in the form of oxides and various metal salts, which can be both soluble and insoluble in water, since they and pollutants can enter the food system as pathogenic microorganisms. It should be noted that the total soil contamination is also characterized by the indicator of the gross amount of heavy metals, and the 
availability of these elements for plants and living organisms is determined by the mobile forms of these metals. Therefore, the presence and content of both quantitative and qualitative forms of frozen heavy metals is one of the most important indicators that characterize the sanitary and hygienic situation of the industrial region and nearby localities, with its fauna and flora.

\section{a. The goals and objectives of the research}

Based on the analysis, the goals and objectives of research were set to determine changes in heavy metals in the soil contaminated with heavy metals in the course of the former Shymkent lead plant and the Achisai mining and processing complex located in the Turkestan region. The purpose of the research is to determine and evaluate soil contamination by heavy metals from the influence of non-ferrous metallurgy enterprises of the Republic of Kazakhstan, using the example of lead, cadmium, copper and zinc. To achieve this goal, the task of selection of point samples of soil from the surrounding areas the location of mining and processing complexes that are sources of environmental pollution and the territory of the
Park - recreation areas of the population of megapolis and guests of Shymkent, with the development of technological bases phytoremediation testing heavy metals physical chemical analysis methods and earthworms.

\section{b. Methods of analysis}

Soil contamination with heavy metals in the industrial regions of the mining and processing complex of non-ferrous metallurgy enterprises is carried out by taking point samples of soil weighing at least $15 \mathrm{~kg}$ from the sampling sites to a depth of $0-20 \mathrm{~mm}$ from a square hole, in accordance with, given in tables 1 and 2 .

Analysis of the chemical composition was performed in accordance with, and using regulatory documents using

Arsenic - containing dusts of various stages of lead-zinc production were analyzed from raw materials used in the production of lead, in particular agglomerate, alkali of the refining shop, dust of the agglomeration shop, small items of the agglomeration process, fine and coarse dust of the agglomeration shop and Converter dust.

Table 1. Averaged chemical analysis of raw materials from the Achisai Deposit.

\begin{tabular}{|l|c|c|c|c|c|c|c|c|c|}
\hline Name of object & $\mathrm{Pb}$ & $\mathrm{Cu}$ & $\mathrm{Cd}$ & $\mathrm{Bi}$ & $\mathrm{As}$ & $\mathrm{Sb}$ & $\mathrm{Ag}$ & $\mathrm{Zn}$ & $\mathrm{Al}_{2} \mathrm{O}_{3}$ \\
\hline Achisai Deposit & 18.87 & 3.5 & 0.041 & $\mathrm{H} / \mathrm{o}^{*}$ & 0.64 & 0.2 & 615.0 & 116 & 3.5 \\
\hline
\end{tabular}

Table 2. Average chemical composition of dusts of various stages of lead-zinc production.

\begin{tabular}{|c|c|c|c|c|c|c|c|c|}
\hline \multirow[b]{2}{*}{ Name of material } & \multicolumn{8}{|c|}{ Component content in $\%$, } \\
\hline & $\mathrm{Pb} \%$ & $\mathrm{Zn} \%$ & $\mathrm{Cu} \%$ & $\mathrm{Fe} \%$ & $\mathrm{~S} \%$ & $\mathrm{Sb} \%$ & As $\%$ & $\begin{array}{c}\mathrm{CaO} \\
\%\end{array}$ \\
\hline Dust of fine purification & 39,79 & 15,19 & 10,94 & 3,2 & 8,3 & 0,51 & 1,0 & no trace ${ }^{*}$ \\
\hline Dust of dry purification & 39,9 & 8,88 & 2,06 & 7,87 & 14,37 & 0,34 & 0,37 & \\
\hline Cyclone dust of high furnace & 32,37 & 7,987 & 2,32 & 9,84 & - & 0,19 & 0,65 & 1,62 \\
\hline Cyclone dust of agglomeration shop & 38,68 & 7,32 & 2,69 & 9,2 & 11,74 & 0,16 & 0,404 & 2,54 \\
\hline Converter dust & 63,33 & 3,47 & 1,82 & 0,23 & & 0,66 & 7,08 & \\
\hline Converter dust from OPS to SNR : 6 & 29,9 & 1,79 & 40,82 & & & & 5,51 & \\
\hline
\end{tabular}

\section{RESULTS AND DISCUSSION}

As a result of the selection and analysis of point samples from various places in the industrial region of the South of the
Republic of Kazakhstan, the excess content of the studied heavy metal components of the MPC standards was revealed.

Table 3. Analysis of samples from various points in the industrial region of the South of the Republic of Kazakhstan.

\begin{tabular}{|c|c|c|c|c|c|c|c|}
\hline \multirow{2}{*}{ № } & \multirow{2}{*}{ Objects } & \multicolumn{5}{|c|}{ Components content, mg/kg } & \multirow{2}{*}{$\begin{array}{l}\text { Method of } \\
\text { testing }\end{array}$} \\
\hline & & $\mathbf{P b}$ & Cd & $\mathbf{Z n}$ & $\mathrm{Cu}$ & As & \\
\hline 1 & Shymkent dendropark & 4,0 & 1,0 & 10,0 & 0 & 0 & \multirow{4}{*}{ MU08-47/203 } \\
\hline 2 & Achisai (Turkestan region) & 1287 & 37 & 871 & 344 & 0,64 & \\
\hline 3 & $\begin{array}{l}\text { Internal overburden rocks formed at mining of } \\
\text { brown coals of the Lenger Deposit (Tolebi region) }\end{array}$ & 461 & 10 & 871 & 62 & 0,59 & \\
\hline 4 & $\begin{array}{l}\text { JSC «Industrial Corporation } \quad \text { Yuzhpolimetall», } \\
\text { Shymkent }\end{array}$ & 1287 & 37 & 7164 & 344 & 0,68 & \\
\hline & MPC & 32,0 & $0,5-1,0$ & 23 & 23 & 2,0 & \\
\hline
\end{tabular}


International Journal of Engineering Research and Technology. ISSN 0974-3154, Volume 13, Number 6 (2020), pp. 1120-1125

(C) International Research Publication House. https://dx.doi.org/10.37624/IJERT/13.6.2020.1120-1125

The elemental and morphological composition of samples of point samples from various locations of the research objects, carried out on the electronic raster microscope JSM-6490LV, designed for measuring the linear dimensions of the microrelief of solid structures, is shown in figures $1,2,3$ and 4 with tabular data.
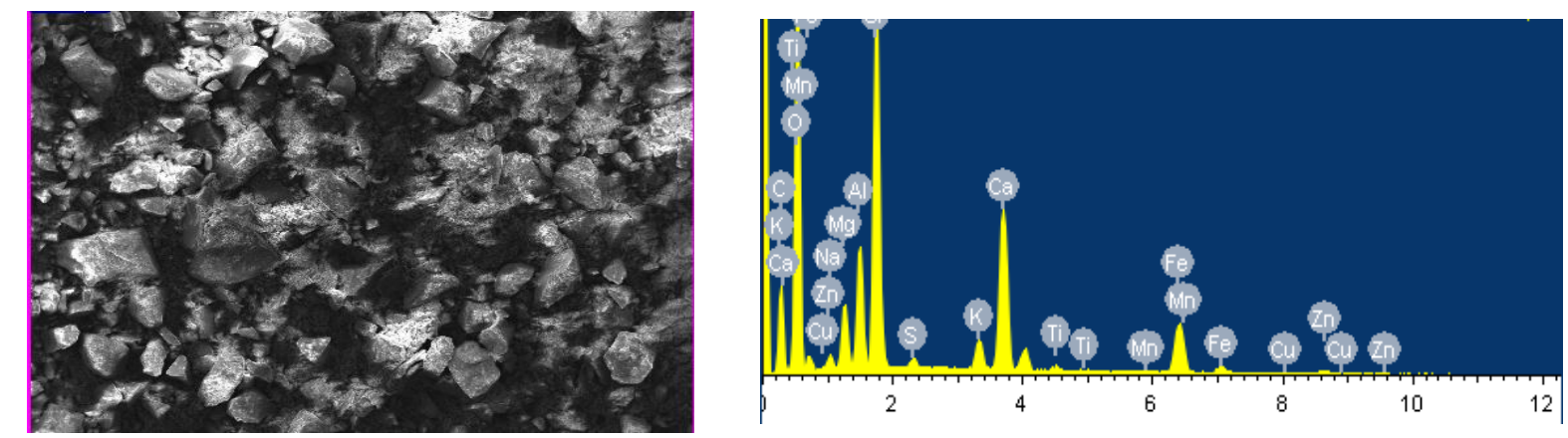

\begin{tabular}{|c|l|l|l|l|l|l|l|l|l|l|}
\hline Element & $\mathrm{Cl}$ & $\mathrm{As}$ & $\mathrm{Al}$ & $\mathrm{Si}$ & $\mathrm{P}$ & $\mathrm{Fe}$ & $\mathrm{K}$ & $\mathrm{Ca}$ & $\mathrm{Zn}$ & $\mathrm{Pb}$ \\
\hline Weight $\%$ & 0,88 & 4,39 & 1,32 & 3,19 & 1,34 & 5,97 & 0,68 & 3,56 & 2,36 & 22,99 \\
\hline
\end{tabular}

Figur 1. Morphological and chemical compositions of soil samples of the complex «Achisay».
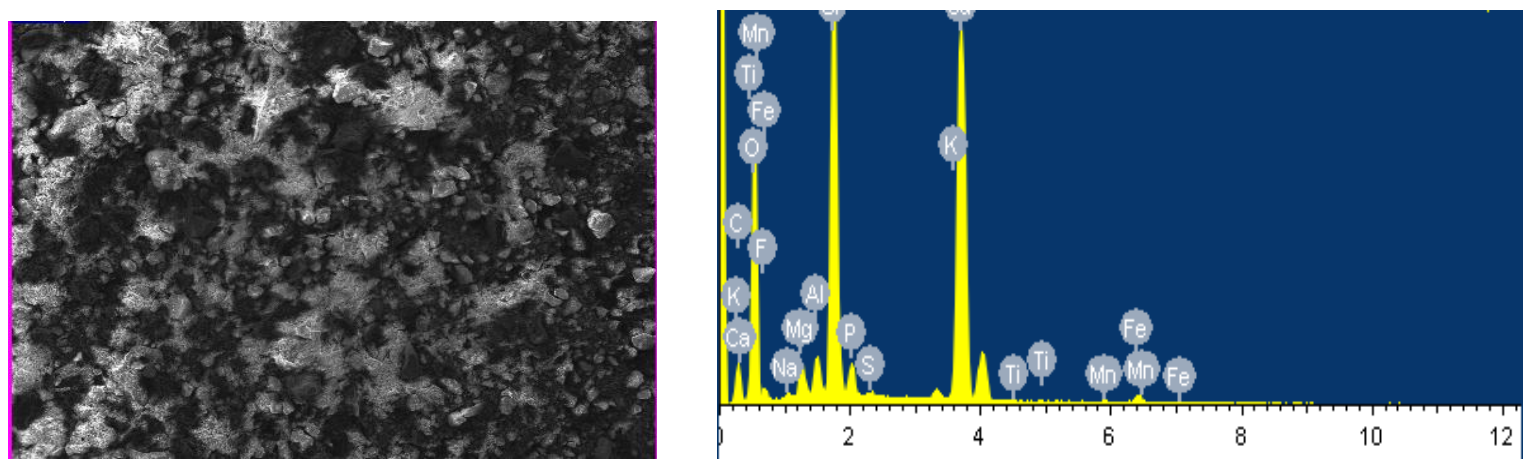

\begin{tabular}{|l|l|l|l|l|l|l|l|l|l|l|}
\hline Element & $\mathrm{Cl}$ & $\mathrm{As}$ & $\mathrm{Al}$ & $\mathrm{Si}$ & $\mathrm{P}$ & $\mathrm{Fe}$ & $\mathrm{K}$ & $\mathrm{Ca}$ & $\mathrm{Zn}$ & $\mathrm{Ti}$ \\
\hline Weight $\%$ & 10,93 & 46,74 & 21.06 & 13,12 & 1,38 & 1,37 & 1,23 & 3,56 & 2,36 & 22,99 \\
\hline
\end{tabular}

Figur 2. Morphological and chemical compositions of soil samples of internal overburden rocks formed during the extraction of brown coal of the Lenger Deposit (Tolebi region)
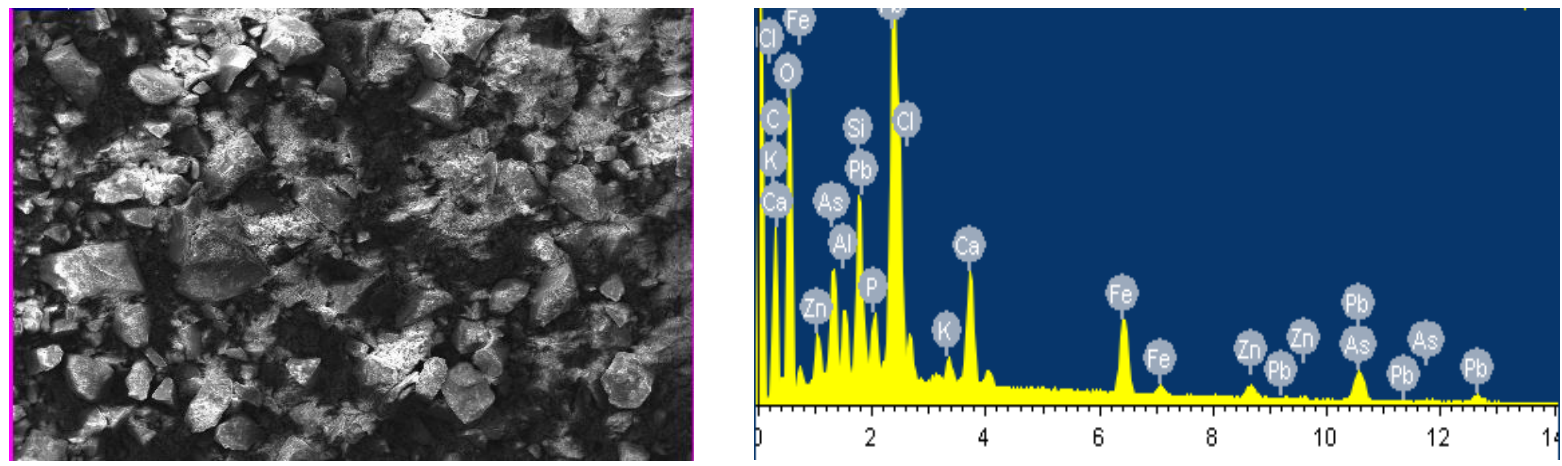

\begin{tabular}{|l|l|l|l|l|l|l|l|l|l|l|}
\hline Element & $\mathrm{C}$ & $\mathrm{O}$ & $\mathrm{Ca}$ & $\mathrm{Si}$ & $\mathrm{Na}$ & $\mathrm{Mg}$ & $\mathrm{Al}$ & $\mathrm{K}$ & $\mathrm{S}$ & $\mathrm{Ti}$ \\
\hline Weight $\%$ & 22,13 & 44,64 & 7,61 & 9,97 & 0,42 & 2,36 & 3,61 & 1,21 & 0,28 & 0,30 \\
\hline
\end{tabular}

Figur 3. Morphological and chemical compositions of soil samples of JSC «Industrial Corporation Yuzhpolimetall», Shymkent 

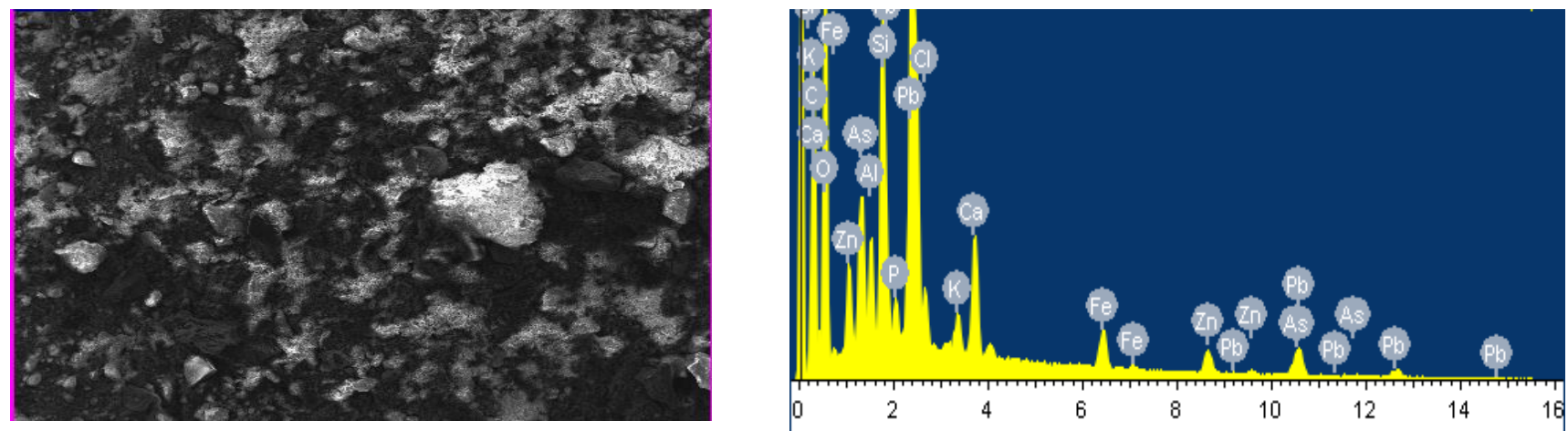

\begin{tabular}{|l|l|l|l|l|l|l|l|l|l|l|}
\hline Element & $\mathrm{C}$ & $\mathrm{O}$ & $\mathrm{Ca}$ & $\mathrm{Si}$ & $\mathrm{Na}$ & $\mathrm{Mg}$ & $\mathrm{Al}$ & $\mathrm{K}$ & $\mathrm{S}$ \\
\hline Weight $\%$ & 0,77 & 4,01 & 1,40 & 4,31 & 0,68 & 2,16 & 0,80 & 2,76 & 3,12 & 19,35 \\
\hline
\end{tabular}

Figur 4. Morphological and chemical compositions of soil samples (control) of Shymkent dendropark

\section{CONCLUSION}

Based on the analysis of point samples on the scanning electron microscope JSM-6490LV, it was revealed that the content of heavy metals in the soils of the studied industrial enterprises is above the MPC (Pb-32.0, Cd-0.5-1.0, $\mathrm{Zn}-23$, $\mathrm{Cu}-23$, As-2.0), which causes irreparable damage to the fauna and flora of the studied regions of the Turkestan region and requires the development of methods for bioremediation control of the soil and a method for cleaning the soil from heavy metals.

The analysis of domestic and foreign literature is carried out patent information on heavy soil cover contamination metals such as lead, copper, zinc, vanadium, Nickel, arsenic, cadmium etc. Sources of formation of heavy metals in the Aktobe region of the plant NTK "Kazchrome - chrome", in the Eastern -2 enterprises in Kazakhstan region, 3 - 4 in Turkestan region companies.

2. Selected spot samples pollution of the earth pricevolume territories. The morphological and chemical composition was also analyzed the selected soils. The content of heavy metals in the samples on the JSM-6490LV scanning electron microscope, contents heavy metals in excess of the MPC, which requires the use of cardinal the decision on bioremediation. The method of soil purification from heavy metals is shown metals'.

\section{ACKNOWLEDGMENTS}

The authors would like to express deep gratitude to the senior researcher of the research department of M. Auezov Aldanazarova G.O. for the technical details of the article

\section{AUTHOR CONTRIBUTIONS}

G.D. (Associate Professor) - development of the research concept. A.D.(PhD) - review of publications on the topic of the article. I. N. (Professor)-statistical processing of the received data. A.D.( Associate Professor ) - writing the first version of the article. K. T. ( Professor) - final approval of the article for publication.

\section{REFERENCES}

[1] Brown SL, Chaney RL, Scott Angle J. Zinc and cadmium uptake by hyperaccumulator thlaspicaerulescens grown in nutrient solution. Soil Sci Soc Am J. 1995;59(1):125-133

[2] Caille B, Vauleon C, Leyval C. Metal transfer to plants grown on a dredged sediment: Use of radioactive isotope $\mathrm{Hg}-203$ and titanium. Sci Total Environ. 2005;341(1-3):227-239.

[3] Cosio C, Martinoia E, Keller C. Hyperaccumulaton of cadium and zinc in Thlaspi caerulescens and Arabidopsis hallri at leaf cellular level. Plant Physiol. 2004;134(2): 716-725.

[4] Ebbs SD, Lasat MM, Brady DJ, Cornish J, Gordon R, Kochian IV. Phytoextraction of cadmium and zinc from a contaminated soil. $J$ Environ Qual. 1997;26(5):1424-1430

[5] Chernykh N. A., Ovcharenko M. M., Popovicheva L. P., Chernykh I. N. 1995. Methods of reducing of phytotoxicity of heavy metals / / Agrochemistry. 2005;2 (9):101-107

[6] Garbisu C, Alkorta I. Phytoextraction: A cost effective plant-based technology for the removal of metals from the environment. Biores Technol. 2001;77(3):229236.

[7] Giller KE, Witter E, McGrath SP. Toxicity of heavy metals to microorganism and microbial processes in agricultural soils: A review. Soil Biol Bichem. 1998;30(10-11): 1389-1414.

[8] Nriagu JO, Pacyna JM. Quantitative assessment of worldwide contamination of air water and soils by trace metals. Nature. 1988;333(6169):134-139.

[9] Postnikov D.A. Patent Ru2365078C1. Method of soil purification from heavy metals. (21) (22) Application: 2017137084, 10.20.2017, (24) Date of commencement of the term of validity of a patent:10/20/2017. Registration Date:08/28/2018 (45) Published: 
08/28/2018 bull. No. 25

[10] Ragnarsdottir KV, Hawkins D. Trace metals in soils and their relationship with scrapie occurrence. Geochimica et Cosmochimica Acta. 2005;69(10):196196.

[11] Muthusaravanan S., Sivarajasekar N., Vivek J.S., Paramasivan T. et.al. Phytoremediation of heavy metals: mechanisms, methods and enhancements. Environmental Chemistry Letters. 2018;8(4):618-625

[12] Pavlichenko L. M., Espolayeva A. R., Iztayeva A. M. The content of heavy metals in the soil of Mangistau region International journal of applied and fundamental research, 2016;2(1):53-58

[13] Arthur E.L., Phytoremediation an over-view. Critical Reviews in Plant Sciences journal. 2005;24:109-122

[14] Awual M.R., Hasan M.M., Eldesoky G.E. etal. Facile mercury detection and removal from aqueous media involving ligand impregnated conjugate nanomaterials. Chemical Engineering Journal. 2016;290:243-251

[15] Ayoub K., Hullebusch E.D., Cassir M., Bermond A. Applica-tion of advanced oxidation processes for TNT removal. Journal of Hazardous Materials. 2010;178:10-28.

[16] Bagga D.K., Peterson S. Phytoremediation of arseniccontami-nated soil as aff ected by the chelating agent CDTA and different levels of soil pH. Remediation. $2001 ; 12: 77-85$.

[17] Baghour M., Moreno D.A., Hernández J. et.al. Influence of root temperature on phytoaccumulation of $\mathrm{As}, \mathrm{Ag}, \mathrm{Cr}$, and $\mathrm{Sb}$ in potato plants (Solanum Tuberosum L. var. Spunta). Journal of Environmental Science and Health, Part A: Toxic/Hazardous. 2001; 36:1389-1401.

[18] Bakar A., Farid A., Yusoff I., Fatt N.T., Othman F., Ashraf M.A. Arsenic, zinc, and aluminium removal from gold mine waste-water effluents and accumulation by submerged aquatic plants. BioMed Research International. 2013;3(9):1-7.

[19] Sneller FEC, van Heerwaarden LM, Schat H. Toxicity, metal uptake, and accumulation of phytochelatins in silene vulgaris exposed to mixtures of cadmium and arsenate. Environ Toxicol Chem. 2000;19(12):29822986.

[20] Baibotayeva, A. Influence of heavy metals (As, Pb, Cd) on the environment / A. Baibotayeva, G. Kenzhaliyeva, V. Bosak // Industrial Technology and Engineering. -2019 . - Nr. 2. - P. 5-10 